\title{
A Computational Investigation of Allostery in the Catabolite
}

\section{Activator Protein}

\author{
Liwei Li, ${ }^{* \dagger}$ Vladimir N. Uversky, ${ }^{* \dagger}$ A. Keith Dunker, ${ }^{* \dagger}$ and Samy O. Meroueh ${ }^{* \dagger \delta}$
}

*Department of Biochemistry and Molecular Biology, Indiana University School of Medicine, Indianapolis, Indiana 46202; ${ }^{\dagger}$ Center for Computational Biology and Bioinformatics, Indiana University Purdue University Indianapolis, Indianapolis, Indiana 46202; ${ }^{\delta}$ Department of Chemistry, Indiana University Purdue University Indianapolis, Indiana, $46202^{\ddagger}$ Institute of Biological Instrumentation, Russian Academy of Sciences, Pushchino 142290, Russia

Corresponding author: smeroueh@iupui.edu

RECEIVED DATE (to be automatically inserted after your manuscript is accepted if required according to the journal that you are submitting your paper to)

TITLE RUNNING HEAD Allostery in the Catabolite Activator Protein

Complete reference 19:

Case, D. A.; Darden, T. A.; Cheatham, T. E. I.; Simmerling, C. L.; Wang, J.; Duke, R. E.; Luo, R.; Merz, K. M.; Pearlman, D. A.; Crowley, D. M.; Walker, R. C.; Zhang, J.; Wang, B.; Hayik, S.; Roitberg, A.; Seabra, G.; Wong, K. F.; Paesani, F.; X., W.; Brozell, S.; Tsui, V.; Gohlke, H.; Tang, L.; Tan, C.; Morgan, J.; Hornak, V.; Cui, G.; Beroza, P.; Matthews, B. H.; Schafmeister, C.; Ross, W. S.; Kollman, P. A. AMBER 9, University of California San Francisco: San Francisco, 2006. 